\title{
Phenotypic Characterization of Jawa Brebes (Jabres) Cattle
}

\author{
Adinata Y, Aryogi, Pamungkas D, Luthfi M, Rasyid A, Krishna NH \\ Indonesian Beef Cattle Research Station \\ Jl. Pahlawan No. 2, Grati, Pasuruan 67184, East Java, Indonesia \\ yudiku98@gmail.com
}

\begin{abstract}
The aim of this study was to identify the relationship among body measurements in Jabres cattle. A total of 193 cows were used. The parameters recorded were: body length (BL), withers height (WH), rump height (RH), rump length (RL), rump width (RW), heart girth (HG), shoulder width (SW), chest depth (CD), face length (FL), and face width (FW). The results showed that the mean body weight was $260,868 \mathrm{~kg}$ while the body measurements were $109.732 ; 115.572 ; 119.158$; 31.674; $11.589 ; 147.169 ; 31.341 ; 55.892 ; 40.915$; and $17.242 \mathrm{~cm}$ for BL, WH, RH, RL, RW, HG, SW, CD, FL, and FW respectively. The coefficients of correlation obtained were: $r=0.269$ (BW $\mathrm{BL}$ ), $\mathrm{r}=0.451(\mathrm{BW}-\mathrm{WH}), \mathrm{r}=0.464(\mathrm{BW}-\mathrm{RH}), \mathrm{r}=0.123(\mathrm{BW}-\mathrm{RL}), \mathrm{r}=0.309(\mathrm{BW}-\mathrm{RW}), \mathrm{r}=$ $0.502(\mathrm{BW}-\mathrm{HG}), \mathrm{r}=0.519(\mathrm{BW}-\mathrm{SW}), \mathrm{r}=0.443(\mathrm{BW}-\mathrm{CD}), \mathrm{r}=0.269(\mathrm{BW}-\mathrm{FL})$, and $\mathrm{r}=0.396$ (BW - FW) respectively. The components were extracted explaining $51.544 \%$ of the total variation. The body measurements could be used as selection criteria for improving body weight of Jabres cattle.
\end{abstract}

Key Words: Jabres Cattle, Phenotypic Characterization, Body Measurements

\section{INTRODUCTION}

Morphometric traits are used to charaterize the different breeds of livestock as they give an idea of body conformation (Pundir et al. 2011). Patterns of development are useful in the assessment of conformation (Salako 2006). Phenotypic characterization is used to identify and document diversity within and between distict breeds, based on their observable attributes (FAO 2012). It is important to have knowledge of the variation of morphometric traits in local genetic resources as such measurements have been discovered to be very useful in comparing body size and by implication, shape of animals. Significant differences in different body measurement traits due to age and sex reported by Pundir et al. (2007a; 2007b; 2007c) Pundir \& Singh (2008), Singh et al. (2008) and Yakubu et al. (2009). Such comparison could be used as basis for selection and improvement programmes. Growth is controlled by both genetic and non-genetic factors (Kor et al. 2006). Body dimensions have been used to indicate breed, origin and relationship or shape and size of an individual, height at withers as a prime indicator for their type. Weighing is not always feasible and therefore live weight is often estimated from easily accessible morphometric data (Mutua et al. 2011). For genetic improvement, principal components simultaneously consider a group of attributes which may be used for selection purpose. In genetic terms, every ecological niche (i.e. ecological zone or environment) is governed by its own peculiar variability.

Jabres cattle is one of the recognized breeds of indonesian cattle and has an excellence in the tropical environment among the indonesian other breeds. body measurements is one of the important criteria in selection of elite animals. There is an urgent need to describe the body conformation by recording a minimum number of body measurements/biometric traits which reduce the cost, labor and time, relationships among different body measurements to define which of these measures best represent body conformation and to formulate suitable breeding policy for improvement of cattle productivity in Jabres cattle. 
Analysis of variance and correlations are used to obtain relationships among different body measurements.

\section{MATERIAL AND METHODS}

\section{Collecting data of morphostructural traits}

The experiment made use of a random sample of 193 Jabres cattle of female sexes. The animals were more than four years old as determined by dentition. They were reared through the extensive management system and originated from different herds sampled in Brebes Region in Central Java, Indonesia. Efforts were made to restrict sampling to phenotipically pure Jabres cattle respectively by measuring only those that conformed to the classification descriptors of the breed.

Body weight of individual cattle was measured using a digitally weigh scale of 1.000 $\mathrm{kg}$ with a precision of $500 \mathrm{~g}$. Ten morphometric traits were measured on each animal. The parts measured were, body length (BL), measured from distance from the point of the shoulder joint to the point of the pin bone, withers height $(\mathrm{WH})$, distance from distance from the highest point of wither to the ground; rump height $(\mathrm{RH})$, the distance from the highest point of rump to the ground; rump length (RL), rump width (RW) and width of hips (Tuber coxae), measured from hips (Tuber coxae) to pins (Tuber ischii), heart girth (HG), measured as body circumference just behind the forelegs, shoulder width (SW), measured as the distance from left to right upper arm (pars cranialis of the tuberculum majus humeri), chest depth (CD), the distance from the higest point of weither to the cest bone just behind the forelegs; face length (FL), distance from between the horn site to the lower lip, face widht $(\mathrm{FW})$, the distance between front of both the eyes, the height measurement $(\mathrm{cm})$ was done using a graduated measuring stick. To achieve this, animals were placed on a flat ground and held by two field assistants. The length and circumference measurements $(\mathrm{cm})$ were effected using a tape rule while the width measurements $(\mathrm{cm})$ were taken using a calibrated wooden calliper. All measurements were car ried out by the same person in order to avoid between individual variations.

\section{Data analysis}

The morphological traits were subjected to analysis of means, standard errors and coefficient of variation of body weight and body measurements of the cattle. Pearson correlation coefficients among the body measurements were calculated and the multiple regression procedure was used to obtain models for predicting body weight from body measurements (a) and from factor scores (b).
(a). $B W=a+B_{1} X_{1}+\ldots+B_{k} X_{k}$
(b). $\mathrm{BW}=\mathrm{a}+\mathrm{B}_{1} \mathrm{FS}_{1}+\ldots+\mathrm{B}_{\mathrm{k}} \mathrm{FS}_{\mathrm{k}}$

Where, $\mathrm{BW}$ is the body weight, $\mathrm{a}$ is the regression intercept, $\mathrm{B}_{i}$ is the $\mathrm{i}^{\text {th }}$ partial regression coefficient of the $\mathrm{i}^{\text {th }}$ linear body measurement $\left(\mathrm{X}_{i}\right)$ or the $\mathrm{i}^{\text {th }}$ factor scores (FS), i: $1, \ldots, k$. The analysis were obtained using IBM SPSS Statistic 20.

\section{RESULTS DISCUSSION}

\section{Phenotype base on the morphostructural traits}

Table 1 shows the descriptive statistics for body weight and body measurement traits of Jabres cattle. The mean body weight was $260.868 \mathrm{~kg}$ while the body measurements were $109.732 \mathrm{~cm}(\mathrm{BL}), 115.572 \mathrm{~cm}(\mathrm{WH}), 119.158 \mathrm{~cm}(\mathrm{RH}), 31.674 \mathrm{~cm}(\mathrm{RL}), 11.589 \mathrm{~cm}$ 
(RW), $147.169 \mathrm{~cm}(\mathrm{HG}), 31.341 \mathrm{~cm}(\mathrm{SW}), 55.892 \mathrm{~cm}(\mathrm{CD}), 40.915 \mathrm{~cm}(\mathrm{FL})$, and 17.242 $\mathrm{cm}(\mathrm{FW})$ respectively.

The skeletal dimensions of RL, RW, SW, BL, were more variable (coefficient of variation ranged from 10.963 to $25.154 \%$ ) compared to $\mathrm{CD}, \mathrm{HG}, \mathrm{FW}, \mathrm{FL}, \mathrm{WH}, \mathrm{RH}$ (coefficient of variation ranged from 4.436 to $9.648 \%$ ).

Table 1. Mean, standard deviation (SD) and coefficient of variation (CV \%) for live body weight and body measurements of Jabres cattle

\begin{tabular}{lcrc}
\hline \hline Parameter & Mean & SD & CV \\
\hline BW (kg) & 260.868 & 35.785 & 13.718 \\
BL (cm) & 109.732 & 12.030 & 10.963 \\
WH (cm) & 115.572 & 5.529 & 4.784 \\
RH (cm) & 119.158 & 5.286 & 4.436 \\
RL (cm) & 31.674 & 7.967 & 25.154 \\
RW (cm) & 11.589 & 1.378 & 11.892 \\
HG (cm) & 147.169 & 13.109 & 8.907 \\
SW (cm) & 31.341 & 3.513 & 11.208 \\
CD (cm) & 55.892 & 5.393 & 9.648 \\
FL (cm) & 40.915 & 2.277 & 5.566 \\
FW (cm) & 17.242 & 1.300 & 7.538 \\
\hline
\end{tabular}

BW: Bogy weight; BL: Body length; WH: Withers height; RH: Rump height; RL: Rump length; RW: Rump width; HG: Heart girth; SW: Shoulder width; CD: Chest depth; FL: Face length; FW: Face width

The estimates for body length, height at withers and heart girth were in close agreement with the reports of Pundir et al. (2007a; 2007b) and Singh et al. (2008). Facial and head differences are very important from an ethnological point of view in breed identification, the ethnological differences, are the basic concepts on the foundation of a breed (Alfranca 2001). Morphology expresses a strong relationship with productive potential, since it contains the structure which supports the biological functionality of the animal (Alpak et al. 2009). The body measurements related to meat value (rump length, chest width, heart girth), these morphostructural changes are related to changes in the productive performance of the animal format; therefore, in the sustained selection process, not only changes in ethnological traits are involved, but also productive traits (Yakubu 2010; Yakubu et al. 2010a; 2010b). Performance especially with regards to meat production can be assessed from body measurements that are less closely associated with bone growth.

Morphostructure provides information susceptible to be used on ethnological characterization of an animal population, and allows a judgment of the productive potential based on the implicit mechanical relationships within the morphologic structure (Yakubu 2010). If the relationship is not considered, it would imply that appropriate productive life adaptation models would not be right (Alpak et al. 2009). It is the diversity in genetic characteristics that enable different animal races to survive in different climatic zones of the world (Yunusa et al. 2013).

Body weight related highly with most of the original body measurements of Jabres cattle. This is suggestive of their possible usage (i.e. the body measurements) in the prediction of body weight in Jabres cattle. This is because an increase in any of the body 
measurement will invariably lead to a corresponding increase in the body weight of Jabres cattle. The strong relationship existing between body weight and most of the original body measurements may be useful as a selection criterion. This is because correlated traits are more likely to be governed by the same gene action.

The coefficient of correlation of body weight and body measurements of Jabres cattle is presented in Table 2. The correlation ranged from $r=-0.331$ to $r=0.697$. The relationships between body weight and all the body measurements majority was positive, there are only three were negative $(-0.331$ for RW-RL, -0.149 for RW-BL, and -0.059 for FL-RW). There are 44 relationships which were highly significant $(\mathrm{P}<0.01)$, three relationships which were significant $(\mathrm{P}<0.05)$ and eight relationships which were non significant. The highest correlation was obtained between RH-WH while correlation between FW-RW was observed to be the least.

Table 2. Correlation coefficients between live body weight and body measurements of Jabres cattle

\begin{tabular}{|c|c|c|c|c|c|c|c|c|c|c|c|}
\hline & BW & BL & WH & RH & RL & RW & HG & SW & $\mathrm{CD}$ & FL & FW \\
\hline BW & 1 & & & & & & & & & & \\
\hline BL & $0.269^{* *}$ & 1 & & & & & & & & & \\
\hline WH & $0.451^{* *}$ & $0.435^{* *}$ & 1 & & & & & & & & \\
\hline RH & $0.464^{* *}$ & $0.236^{* *}$ & $0.697^{* *}$ & 1 & & & & & & & \\
\hline RL & 0.123 & $0.667^{* *}$ & $0.375^{* *}$ & 0.105 & 1 & & & & & & \\
\hline RW & $0.309^{* *}$ & $-0.149^{*}$ & 0.053 & $0.192^{* *}$ & $-0.331^{* *}$ & 1 & & & & & \\
\hline $\mathrm{HG}$ & $0.502^{* *}$ & 0.129 & $0.346^{* *}$ & $0.289^{* *}$ & 0.074 & $0.248^{* *}$ & 1 & & & & \\
\hline SW & $0.519^{* *}$ & $0.334^{* *}$ & $0.467^{* *}$ & $0.339^{* *}$ & $0.351^{* *}$ & $0.145^{*}$ & $0.237^{* *}$ & 1 & & & \\
\hline $\mathrm{CD}$ & $0.443^{* *}$ & $0.391^{* *}$ & $0.436^{* *}$ & $0.309^{* *}$ & $0.324^{* *}$ & 0.097 & $0.247^{* *}$ & $0.397^{* *}$ & 1 & & \\
\hline FL & $0.269^{* *}$ & $0.451^{* *}$ & $0.487^{* *}$ & $0.283^{* *}$ & $0.495^{* *}$ & -0.059 & $0.169^{*}$ & $0.363^{* *}$ & $0.349^{* *}$ & 1 & \\
\hline FW & $0.396^{* *}$ & $0.275^{* *}$ & $0.345^{* *}$ & $0.284^{* * *}$ & $0.286^{* *}$ & 0.042 & $0.275^{* *}$ & $0.307^{* *}$ & $0.261^{* *}$ & $0.348^{* *}$ & 1 \\
\hline
\end{tabular}

*Correlation is significant at the 0.05 level; **Correlation is significant at the 0.01 level

Table 3. Multiple regression of live body weight $(\mathrm{kg})$ on original body measurements of Jabres cattle

\begin{tabular}{|c|c|c|c|c|c|}
\hline Step & Predictor & Intersept & Regression coeffisient & $\mathrm{SE}$ & $\mathrm{R}^{2}$ \\
\hline \multicolumn{6}{|c|}{ Original body measurements as independent variables } \\
\hline \multirow[t]{10}{*}{1} & BL & -246.790 & 0.332 & 24.91 & 0.541 \\
\hline & WH & & -0.219 & & \\
\hline & RH & & 1.225 & & \\
\hline & RL & & -0.629 & & \\
\hline & RW & & 2.898 & & \\
\hline & HG & & 0.758 & & \\
\hline & SW & & 2.956 & & \\
\hline & $\mathrm{CD}$ & & 1.133 & & \\
\hline & FL & & -0.073 & & \\
\hline & FW & & 4.196 & & \\
\hline
\end{tabular}

SE: Standard error of estimate; $\mathrm{R}^{2}$ : Coefficient of determination 
The results of regression analysis for predicting live body weight from the ten interdependent body measurements of Jabres cattle showed that $54.1 \%$ of the variability in live body weight when all the body measurements (BL, WH, RH, RL, RW, HG, SW, CD, $\mathrm{FL}$, and FW) were used in the equation.

\section{CONCLUSION}

This study revealed the interdependency of the ten original body measurement characters on each other. the analysis was discovered to be a more appropriate means of predicting live body weight in Jabres cattle than the use of the original interrelated traits measured. The body measurement of face widht, shoulder width, rump width, rum height, chest depth, heart girth, and body length could be used as selection criteria for improving body weight of Jabres cattle.

\section{ACKNOWLEDGEMENT}

This research was supported by BCATRES Indonesia. Thank you to all staff at the BCATRES Indonesia which support the facilities for this research.

\section{REFERENCES}

Alpak H, Onar V, Mutus R. 2009. The relationship between morphometric and long bone measurements of the Morkaraman sheep.Turk J Vet Anim Sci. 33:199-207.

Alfranca IS. 2001. The breed concept: evolution and reality. Arch Zootec. 50:547-64.

FAO. 2012. Phenotipic characterization of animal genetic resources. Animal production and health guideline no. 11. Rome (Italy): FAO.

Kor A, Baspinar E, Karaca S, Keskin S. 2006. The determination of growth in Akkeci (white goat) female kids by various growth models. Czech J Anim Sci. 51:110-116.

Mutua FK, Dewey CE, Arimi SM, Schelling E, Ogara WO. 2011. Prediction of live body weight using length and girth measurements for pigs in rural Western Kenya. J Swine Health Prod. 19:26-33.

Pundir RK, Pathak BL, Ahalawat SPS. 2007a. Characterization and evaluation of Kankrej breed of cattle in its native tract. Indian J Anim Sci. 77:323-327.

Pundir RK, Singh PK. 2008. Status, characteristics and performance of Red Kandhari cattle breed in its native tract. Indian J Anim Sci. 78:56-61.

Pundir RK, Singh PK, Prakash B, Ahlawat SPS. 2007c. Characterization and evaluation of Kenkatha breed in its native tract. Indian J Anim Sci. 77:177-180.

Pundir RK, Singh PK, Singh KP, Dangi PS. 2011. Factor analysis of biometric traits of Kankrej cows to explain body conformation. Asian Australas J Anim Sci. 24:449-456.

Pundir RK, Singh PK, Uppadhaya SN, Ahlawat SPS. 2007b. Status, characteristics and performance of Red Sindhi cattle. Indian J Anim Sci. 77:755-758.

Salako AE. 2006. Principal component factor analysis of the morpho structure of immature uda sheep. Int J Morphol. 24:571-574.

Singh PK, Pundir RK, Alhawat SPS, Kumar NS, Govindaiah MG, Asija K. 2008. Phenotypic characterization and performance evaluation of Hallikar cattle in its native tract. Indian $\mathbf{J}$ Anim Sci. 78:211-214. 
Yakubu A. 2010. Path coefficient and path analysis of body weight and biometric traits in Yankasa lambs. Slovak J Anim Sci. 43:17-25.

Yakubu A, Salako AE, Imumorin IG. 2010a. Multivariate analysis of spatial patterns of morphological traits in West African Dwarf goats in three agro-ecological zones of Nigeria. $\mathbf{J}$ Appl Anim Res. 38:257-60.

Yakubu A, Ogah DM, Idahor KO. 2009. Principal component analysis of the morphstructural indices of White Fulani cattle. Trakia J Sci. 7:67-73.

Yakubu A, Salako AE, Imumorin IG, Ige AO, Akinyemi MO. 2010b. Discriminant analysis of morphometric differentiation in the West African Dwarf and Red Sokoto goats. S Afr J Anim Sci. 40:381-387.

Yunusa AJ, Salako AE, Oladejo OA. 2013. Morphometric characterization of Nigerian indigenous sheep using multifactorial discriminant analysis. Int J Biodivers and Conserv. 5:661-665. 